\title{
Endemicity of Lymphatic Filariasis in Belitung Regency Post Elimination
}

\author{
$1^{\text {st }}$ Santoso \\ Department of Health Research \\ Development Center \\ Ministry of Health \\ Baturaja, Indonesia \\ santosobaturaja@gmail.com
}

\author{
$2^{\text {nd }}$ Yahya \\ Department of Health Research \\ Development Center \\ Ministry of Health \\ Baturaja, Indonesia \\ agaabdurrahman79@gmail.com
}

\author{
$3^{\text {rd }}$ Yanelza Supranelfy \\ Department of Health Research \\ Development Center \\ Ministry of Health \\ Baturaja, Indonesia \\ yanelza.s@gmail.com
}

\author{
$4^{\text {th }}$ Nungki Hapsari Suryaningtyas \\ Department of Health Research \\ Development Center \\ Ministry of Health \\ Baturaja, Indonesia \\ Nungkihapsari36@gmail.com
}

Corresponding author: agaabdurrahman79@gmail.com

\begin{abstract}
Elimination of filariasis was launched in 2002 in South Sumatra with the target in $\mathbf{2 0 2 0}$ elimination has been done in all endemic regencies. This study aims to obtain factors that cause treatment failure in the prevention of filariasis as well as community based filariasis control efforts.This research has been conducted in Belitung Regency. The research activities included interviews, finger blood surveys of 671 residents, focus group discussions and in-depth interviews. Finger blood surveys in two villages in Belitung Regency obtained a microfilaria rate in Lasar Village, Membalong Sub District of 5.1\% (16 of 311) and Suak Gual Village, Selat Nasik Sub District for $2.2 \%$ (8 of 360). The population who had received drugs in the filariasis MDA activity in Lasar Village was $62.4 \%$ and SuakGual Village was $57.7 \%$. The results of in-depth interviews with cadres and community leaders revealed that some residents did not take filariasis prevention medication because of the side effects of the drug and felt they did not need the drug. The results of an environmental survey found a pool of water overgrown with water plants around the residential areas in Lasar Village and SuakGual Village that have the potential to breed habitat for Mansonia sp. as the main vector filariasis of Brugia malayi.
\end{abstract}

Keywords: filariasis, endemic, mansonia breeding place.

\section{INTRODUCTION}

Lymphatic filariasis, commonly known as elephant foot disease and is a neglected tropical disease. Infections can occur in humans with mosquito as vectors. In 2018, a total of 893 million people in 49 countries lived in areas that carried out preventive medicine activities to stop transmission [1].
Indonesia is one of the countries that are conducting elimination filariasis activities. The number of chronic filariasis in Indonesia is 10,846 spread in 380 districts in 34 provinces. The number of districts endemic to 236 from 514 districts in Indonesia. The activities of mass drug administration (MDA) filariasis in Indonesia has been conducted since 2006, with treatment coverage ranging from $15.40 \%$ (year 2006) to $78 \%$ (year 2019). The minimum Target coverage of MDA filariasis per year is at least $65 \%$ of the county's total population. A total of 118 districts have finished doing MDA for 5 years round and 30 districts have been declared elimination of filariasis [2], [3].

Belitung Regency is one of the districts that have completed the MDA 5-year round and have received a certificate of elimination filariasis from the Ministry of Health of the Republic of Indonesia in 2017. Based on the results of the 2017 research in Belitung district is still found a new case with Microfilaria rate (Mf rate) of $1.3 \%$ [4] so it is necessary to do further research to evaluate the implementation of the program filariasis elimination in Belitung Regency. The purpose of this research is to evaluate the implementation of MDA filariasis resulting in the failure of treatment that has been done so that there is still a new filariasis sufferer.

\section{METHOD}

\section{A. Study area}

The design of this study is a cross section with survey methods. The research was conducted in two villages in Belitung regency for eight months (April- 
November 2019). The chosen village is a village reporting a chronic case. The number of samples for finger blood surveys per village revered by Ministry of Health [5].

The population criteria interviewed were people over 17 years old and those examined in blood were over five years old and willing to be involved in the study by signing informed consent. Sample criteria for blood tests are residents aged over 5 years.

\section{B. Interview of the population}

Before finger blood survey at night, the first visit to a resident's home for interviews in adult populations (over 17 years old). The interview was conducted by a trained officer. Questions posed in the questionnaire include the knowledge and behaviour of the community in connection with the program of the filariasis in the research site. Questions about the behavior of subjects aged less than 17 years are represented by parents or family subjects.

\section{Blood Surveys}

Blood screening is done at the Village Office, Public Health Center, or location that is easily accessible by residents. The residents who came to register and were given explanations about the intent and purpose of the research activities. People who are willing to be involved will sign informed consent, and do a finger blood sampling as much as $60 \mu \mathrm{L}$. Blood samples were made of three lines of thick blood, each with a volume of $20 \mu \mathrm{L}[5]$.

Blood samples were left in room temperature for 24 hours, and then carried out dehemoglobination by soaking in aquades for 10-20 minutes. Then the slide is arranged on the coloring rack until it dries. After the slide is dry, dipped in methanol absolute for 1 second, and is given coloration with a $3 \%$ giemsa. The colored slides are read under the microscope with $10 \mathrm{x}$ magnification for the identification of Microfilaria. When a Microfilarian is found in a slide, further examination is performed with a magnification of $40 \mathrm{x}$ to identify the species and density of microfilaria per slide [6].

\section{R E S U L T S}

The study was conducted in two villages, namely the villages of Suak Gual and Lassar. The results of the analysis of knowledge and behavior about filariasis are presented in tables 1-3

Table 1. Knowledge level about filariasis

\begin{tabular}{crrrrr}
\hline Villa & \multicolumn{2}{c}{ Knowledge level } & Total & $\begin{array}{c}\boldsymbol{P} \\
\text { value }\end{array}$ & 95\% CI \\
\cline { 2 - 3 } & \multicolumn{1}{c}{ Low } & High & & \\
\hline Lass & 238 & 46 & 284 & & \\
ar & $(83.8 \%)$ & $(16.2 \%)$ & $(100 \%)$ & 0,035 & $1.049-$ \\
& & 66 & 280 & & \\
\hline Suak & 214 & $(23.6 \%)$ & $(100 \%)$ & \\
Gual & $(76.4 \%)$ & 112 & 564 & \\
\hline Total & 452 & $(19.9 \%)$ & $(100 \%)$ & \\
& $(80.1 \%)$ & & &
\end{tabular}

Tabel 2. The Proportion of people who get drugs filariasis

\begin{tabular}{lccl}
\multirow{2}{*}{ Village } & \multicolumn{2}{c}{ Following mass treatment } & \multirow{2}{*}{ Total } \\
\cline { 2 - 3 } & Yes & No & \\
\hline Lassar & $168(59.2 \%)$ & $116(40.8 \%)$ & $284(100 \%)$ \\
\hline $\begin{array}{l}\text { Suak } \\
\text { Gual }\end{array}$ & $165(58.9 \%)$ & $115(41.1 \%)$ & $280(100 \%)$ \\
\hline Total & $333(59.0 \%)$ & $231(41.0 \%)$ & $564(100 \%)$
\end{tabular}

Tabel 3. Behavior towards filariasis mass treatment

\begin{tabular}{|c|c|c|c|c|}
\hline \multirow[b]{2}{*}{ Village } & \multicolumn{3}{|c|}{ Medication behavior } & \multirow[b]{2}{*}{ Total } \\
\hline & Yes, all & $\begin{array}{c}\text { Yes, in } \\
\text { part }\end{array}$ & No & \\
\hline Lassar & $\begin{array}{r}139 \\
(82.7 \%)\end{array}$ & $\begin{array}{r}15 \\
(8.9 \%)\end{array}$ & $\begin{array}{r}14 \\
(8.3 \%)\end{array}$ & $168(100 \%)$ \\
\hline $\begin{array}{l}\text { Suak } \\
\text { Gual }\end{array}$ & $\begin{array}{r}144 \\
(87.3 \%)\end{array}$ & $\begin{array}{r}12 \\
(7.3 \%)\end{array}$ & $\begin{array}{c}.9 \\
(5,5 \%)\end{array}$ & $165(100 \%)$ \\
\hline Total & $\begin{array}{r}283 \\
(85.0 \%)\end{array}$ & $\begin{array}{r}27 \\
(8.1 \%)\end{array}$ & $\begin{array}{r}23 \\
(6.9 \%)\end{array}$ & $333(100 \%)$ \\
\hline
\end{tabular}

The level of public knowledge about the filariasis of Lassar and Suak Gual villages is still low. The results of the bivariate analysis found differences in the level of community knowledge in the villages of Lassar and Suak Gual $(\mathrm{p}=0.35)$. Low public knowledge about the causes of filariasis is also found in other regions, such as Northeastern Brazil, which found that the population who knew about filariasis transmission was only $7.8 \%$ [7]. 
The number of people tested for blood was 671 . The results obtained were 24 positive microfilariae (Table $4)$.

Tabel 4. Blood survey results

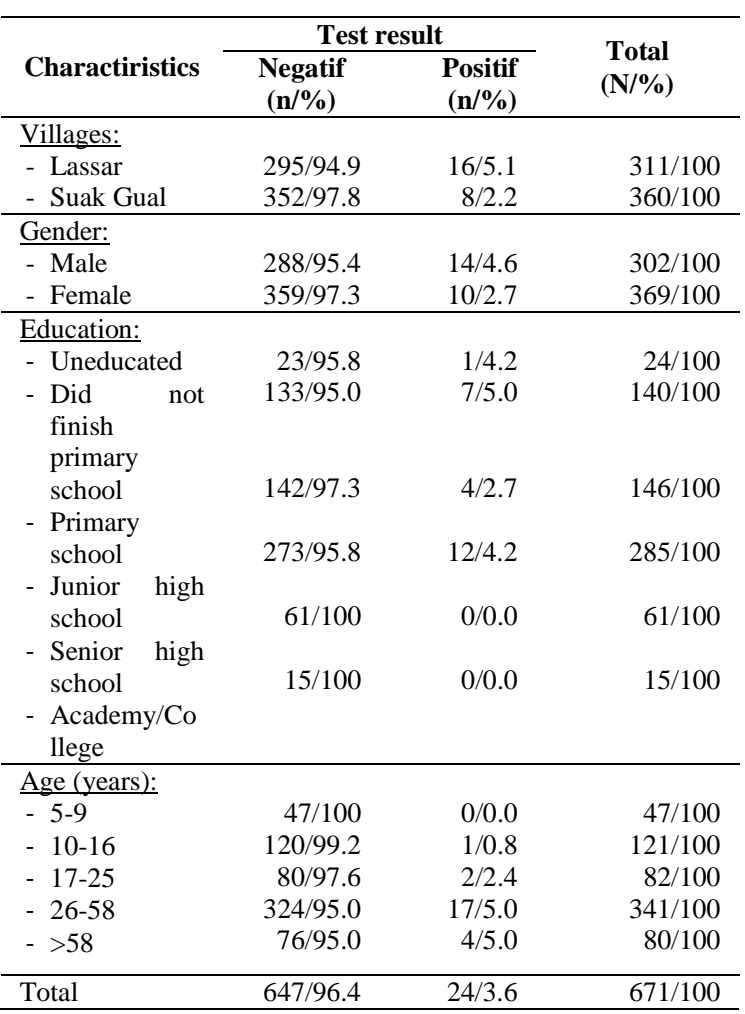

Based on table 4, it is known that in Belitung Regency there are still microfilaremia sufferers found despite mass treatment to prevent filariasis. Surveillance activities after elimination still need to be done to prevent the re-transmission of filariasis. There is a need for support from relevant parties, especially health workers, so that they continue to carry out active surveillance to maintain the elimination status of filariasis[8].

\section{D I S C U S S I O N}

Low public knowledge about fiariasis is due to lack of information about this disease in the community and the existence of other perceptions about this disease. Filariasis or elephant foot disease in some areas of Indonesia is known for a number of terms, including "untut, ular-ularan, or kelenjaran" [9] with special symptoms of bone marrow [10], [11].

Public behavior towards the prevention of filariasis is also still low. The level of community compliance with filariasis prevention medicine is still below the standards set by the Ministry of Health. The minimum mass treatment coverage that must be achieved should be $65 \%$ of the total population. The survey results show that the coverage of the population taking drugs is still below $65 \%$, which is $50.2 \%$. The effects of drugs cause people not to take the drugs that have been given. This happens due to lack of information about these treatment activities. The distribution of drugs carried out by health cadres without being equipped with sufficient knowledge, especially about the reaction of these drugs can cause public distrust of the effectiveness of the MDA filariasis that has been done [12] [13].

The prevalence rate of microfilaremia cases is still relatively high because it is more than $1 \%$. This indicates that the Regency of Belitung still has filariasis transmission. The high prevalence rate is likely due to the low coverage of the population participating in MDA activities, which is less than $60 \%$. Coverage of people who take medicine should be $65 \%$ of the total population or $80 \%$ of the target population who must take medicine[14].

Some of the problems faced in controlling filariasis are problems of access that are difficult to reach, low public education, and lack of public awareness to play a role in controlling filariasis. Routine outreach activities need to be carried out especially in remote areas so that community knowledge and participation in increasing filariasis control activities[15].High population mobility is also one of the challenges in controlling infectious diseases, especially filariasis. Monitoring needs to be done continuously by involving community leaders and health cadres so that the filariasis elimination program can run well[16].

The role of policy makers is very influential on the success of the filariasis control program. This relates to the implementation of the MDA filariasis which is carried out within five years so that it requires financial support and the officer implementing the activity[17].

One of the filariasis surveillance activities that can be done is to search for patients by active means, namely blood tests on residents who experience clinical symptoms of filariasis. The discovery of active patients with follow-up treatment if found positive patients will reduce the risk of further transmission of filariasis, so that the status of elimination of filariasis that has been obtained can be maintained[18]. 
Filariasis surveillance activities also need to be carried out by involving health cadres, community leaders, and the whole community. Filariasis elimination activities are strongly influenced by community support in MDA activities and protecting the environment to reduce mosquito habitat as a vector of filariasis. Monitoring of vectors also needs to be done to identify vectors that have the potential to transmit filariasis. [19], [20]

\section{CONCLUSION}

Knowledge, attitudes and behavior of people towards the prevention of filarasis are still low. Belitung Regency is still a filariasis endemic area with an Mf rate of $5.1 \%$. There needs to be an increase in public knowledge and awareness in order to be willing to participate in filariasis elimination activities

\section{ACKNOWLEDGMENT}

This work supported by Baturaja National Health Research and Development Center.

\section{REFERENCES}

[1] World Health Organization., "Lymphatic filariasis," 2019. [Online]. Available: https://www.who.int/news-room/factsheets/detail/lymphatic-filariasis. [Accessed: 17-Oct-2020].

[2] Dirjen P2TVZ Kemkes, "Strategi Percepatan Penanggulangan Filariasis dan Kecacingan di Indonesia Situasi Filariasis dan Cacingan di Indonesia," Jakarta, 2020

[3] K. D. Ramaiah and E. A. Ottesen, "Progress and Impact of 13 Years of the Global Programme to Eliminate Lymphatic Filariasis on Reducing the Burden of Filarial Disease," vol. 8, no. 11, 2014, doi: 10.1371/journal.pntd.0003319.

[4] S. Santoso et al., "Evaluation of Lymphatic Filariasis Transmission in Riau and Bangka Belitung Province: Parasite Infection on Human and Vector," Balaba J. Litbang Pengendali. Penyakit Bersumber Binatang Banjarnegara, vol 15, no. 2, pp. 115-124, 2019, doi: 10.22435/blb.v15i2.1625.

[5] Ministry of Health, "Guidelines for the determination and evaluation of filariasis endemic areas," in Guidelines for the determination and evaluation of filariasis endemic areas, Jakarta, Indonesia: Ministry of Health, 2012, pp. 1-47.

[6] World Health Organization, Bench Aids for the diagnosis of filarial infections. Geneva: World Health Organization, 1997.

[7] S. Cabral, C. Bonfim, R. Oliveira, and P. Oliveira, "Knowledge, attitudes and perceptions regarding lymphatic filariasis: study on systematic noncompliance with mass drug administration," Rev Inst Med Trop São Paulo, vol. 29, no. 23, pp. 1-9, 2017.

[8] H. Harrington et al., "A practical strategy for responding to a case of lymphatic filariasis post-elimination in Pacific
Islands," Parasites and Vectors, vol. 6, no. 1, pp. 1-7, 2013, doi: 10.1186/1756-3305-6-218

[9] L. P. Ambarita, Y. Taviv, H. Sitorus, R. I. Pahlepi, and Kasnodihardjo, "Perilaku Masyarakat terkait Penyakit Kaki Gajah dan Program Pengobatan Massal di Kecamatan Pemayung Kabupaten Batanghari, Jambi," Media Litbangkes, vol. 24, no. 4, pp. 191-198, 2014.

[10] E. C. Amaechi and O. Ukpai, "Lymphatic filariasis: knowledge, attitude and practices among inhabitants of an irrigation project community, North Central Nigeria," Asian Pac J Trop Dis, vol. 6, no. 9, pp. 709-713, 2016, doi: 10.1016/S2222-1808(16)61114-3.

[11] Santoso, A. Yenni, R. Oktarina, T. Wurisatuti, and K. S. Rahayu, "Pengetahuan, sikap dan perilaku masyarakat pasca pengobatan dan pengaruhnya terhadap endemisitas filariasis di Kabupaten Tanjung Jabung Timur," Spirakel, vol. 7, no. 1, pp. 14-26, 2015.

[12] M. Widawati, E. P. Astuti, A. Ruliansyah, and Y. Yuliasih, "Sociodemographic, Knowledge, and Attitude Determinants of Lymphatic Filariasis Medication Adherence in Subang, Indonesia," Adv. Heal. Sci. Res., vol. 24, no. 94, pp. 1-6, 2020.

[13] A. T. Hapsari, Z. Shaluhiyah, and A. Suryoputro, "Pengaruh Faktor Pendukung terhadap Perilaku Masyarakat dalam Pencegahan Penyakit Filariasis di Kota Semarang," $J$. Promosi Kesehat. Indones., vol. 13, no. 2, pp. 143-154, 2018.

[14] M. H. Hodges et al., "High coverage of mass drug administration for lymphatic filariasis in rural and non-rural settings in the Western Area, Sierra Leone," Parasites and Vectors, vol. 3, no. 1, pp. 1-8, 2010, doi: 10.1186/1756-33053-120.

[15] N. Bhullar and J. Maikere, "Challenges in mass drug administration for treating lymphatic filariasis in Papua Indonesia," Parasit. Vectors, vol. 3, no. 70, pp. 1-7, 2010.

[16] M. H. Hodges, M. Sonnie, H. Turay, A. Conteh, F. Maccarthy, and S. Sesay, "Maintaining effective mass drug administration for lymphatic filariasis through in-process monitoring in Sierra Leone," Parasit. Vectors, vol. 5, no. 1, p. 1, 2012, doi: 10.1186/1756-3305-5-232

[17] Y. Patanduk, R. Yunarko, M. Mading, and J. L. Dara, "Kesiapan Stakeholder Pengobatan Massal Filariasis di Kecamatan Kodi Balaghar Kabupaten Sumba Barat Daya," Bul. Penelit. Kesehat., vol. 46, no. 2, pp. 109-118, 2018.

[18] M. Ipa, E. P. Astuti, A. Ruliansyah, T. Wahono, and L. Hakim, "Gambaran Surveilans Fllariasis di Kabupaten Bandung Provinsi Jawa Barat," J. Ekol. Kesehat., vol. 13, no. 2, pp. 153-164, 2014.

[19] S. R. Irish et al., "Molecular xenomonitoring for Wuchereria bancrofti in Culex quinquefasciatus in two districts in Bangladesh supports transmission assessment survey findings," PLoS Negl. Trop. Dis., vol. 12, no. 7, pp. 1-12, 2018, doi: 10.1371/journal.pntd.0006574.

[20] M. A. Dorkenoo et al., "Molecular xenomonitoring for postvalidation surveillance of lymphatic filariasis in Togo: No evidence for active transmission," Parasites and Vectors, vol. 11, no. 1, pp. 1-9, 2018, doi: 10.1186/s13071-017-2611-9. 